\title{
PERLINDUNGAN HUKUM KEKAYAAN INTELEKTUAL PADA MEREK BERBENTUK HOLOGRAM
}

\author{
Ansyari; Muthia Septarina \\ Fakultas Hukum, Universitas Islam Kalimantan MAB Banjarmasin, \\ Kalimantan Selatan 70123 \\ E-mail: muthiaseptarina01@gmail.com
}

\begin{abstract}
Trademark is the identity of a company. In its current development technology is not far from the innovation and creations of various parties to introduce its mark that has unique characteristics. Hologram is now developing as the result of current technological developments. The purpose of this study is to study the legal protection of hologram as trademarks. This study uses a normative method with a statute approach. The results of the study found that the hologram was contained in Law Number 20 / 2016. It was explained that the hologram entered into a non-traditional trademark. Thus, hologram has legal protection when displaying different colors from the same perspective.
\end{abstract}

Keywords: Intellectual Property Rights, Hologram, Trademarks; Law

\begin{abstract}
Abstrak
Merek merupakan salah satu identitas/ciri khas sebuah perusahaan. Dalam perkembangannya sekarang ini teknologi tidak luput dari adanya inovasi serta kreasi dari berbagai pihak untuk memperkenalkan mereknya yang memiliki ciri khas yang unik. Hologram merupakan salah satu dari jenis merek yang sedang berkembang dan akibat perkembangan teknologi sekarang ini. Tujuan dari penelitian ini untuk mengkaji bagaimana perlindungannya terhadap merek hologram. Penelitian ini menggunakan metode penelitian normatif dengan pendekatan perundang-undangan (statute approach). Hasil penelitian ditemukan merek hologram sudah terdapat didalam Undang-Undang Nomor 20 Tahun 2016. Dijelaskan hologram masuk kedalam merek non-tradisional. kedua, perlindungan hukum terhadap hologram, hologram memiliki perlindungan hukum apabila menampilkan warna yang berbeda dari sudut pandang yang sama.
\end{abstract}

Kata Kunci: Hak Kekayaan Intelektual, Hologram, Merek, Hukum 


\section{PENDAHULUAN}

Di era teknologi yang telah berkembang pesat segala jenis informasi bisa diakses dengan mudah tentu hal ini bukan muncul secara tiba-tiba. Adanya perkembangan ini tidak luput dari inovasi dan kreatifitas dari berbagi pihak. Perkembangan teknologi memiliki sisi poditif dari banyaknya aspek kehidupan yang dipermudah sebagai contoh apabila suatu badan usaha ingin memperkenalkan mereknya yang memiliki ciri khas yang unik kepada para konsumen agar bisa langsung mengingat atau memahami maksud dari perusahaan tersebut baik secara tersirat maupun tersurat.

Pengertian merek sendiri menurut Undang-Undang No 20 Tahun 2016 adalah tanda yang dapat ditampilkan secara grafis berupa gambar, logo, nama, kata, huruf, angka, susunan warna, dalam bentuk dua dimensi dan/atau tiga dimensi, suara, hologram, atau kombinasi dari dua atau lebih unsur tersebut untuk membedakan barang dan/atau jasa yang diproduksi oleh orang atau badan hukum dalam kegiatan perdagangan barang dan/atau jasa.

Merek selain menjadi suatu identitas juga mempunyai fungsi lain yaitu sebagai tanda pengenal untuk membedakan produksi yang dibuat secara individu maupun beberapa orang secara bersamasama atau badan hukum dengan produksi pihak lainnya. Kemudian merek juga dapat menjadi sebagai salah satu alat promosi, tidak hanya itu merek juga berfungsi sebagai jaminan atas mutu suatu barang dan/atau jasa, merek juga sebagai penunjuk darimana asal barang dan/atau jasa tersebut dihasilkan.

Maka dari itu demi melindungi hak dari pemegang merek, perlindungan hukum haruslah diberikan, agar tidak adanya penyalahgunaan. Bisa dikatakan perkembangan teknologi memberikan pengaruh yang sangat besar juga untuk perkembangan hukum serta undangundang, karena setiap teknologi mengalami pembaharuan maka dari aspek hukum pun juga harus ikut diperbaharui. Seperti yang sekarang sedang menjadi tren, yaitu adanya teknologi hologram.

Hologram adalah teknologi yang mampu merekam cahaya yang tersebar dari objek dan menyajikannya dalam bentuk tiga dimensi. Gambar tiga dimensi tersebut kemudian dapat disajikan dalam bentuk 360 derajat dan dapat bergerak dengan animasi dan suara, agar dapat menyampaikan informasi baik secara realtime maupun tidak. Hologram sangat membantu dalam penyampaian informasi terlebih dalam tujuan untuk mempresentasikan suatu merek, karena hologram bisa di desain senyata mungkin sesuai dengan keinginan perusahaan dalam 
penyampaian maksud dan tujuan agar mudah diterima oleh konsumen.

Hologram merupakan salah satu dari sekian banyaknya jenis merek yang sedang berkembang dan masih sedikit orang yang menggunakan serta membuat suatu objek dengan menggunakan teknologi hologram. Hal ini juga yang menjadi alasan mengapa hologram tidak bisa dibuat oleh sembarang orang atau bahkan perlu dibuat secara khusus oleh orang-orang yang memang memiliki keahlian dalam bidang tersebut. Lalu apakah hologram juga termasuk dalam hak merek yang harus memiliki perlindungan hukum bagi setiap pengguna maupun pembuatnya, hal ini membuat penulis tertarik untuk melakukan penelitian ini.

\section{RUMUSAN MASALAH}

Berdasarkan latar belakang diatas dapat dirumuskan masalah yang ingin dikaji yakni terkait bagaimana perlindungan hukum terhadap merek yang berbentuk hologram menurut UndangUndang Nomor 20 Tahun 2016 Tentang Merek dan Indikasi Geografis?

\section{METODE PENELITIAN}

Metode yang digunakan dalam penelitian ini adalah metode penelitian normative yaitu metode atau cara yang dipergunakan di dalam penelitian hukum yang dilakukan dengan cara meneliti bahan pustaka yang ada $^{1}$. Tahapan pertama peneliitian hukum normative adalah penelitian yang ditujukan untuk mendapat hukum obyektif (norma hukum), yaitu dengan mengadakan penelitian tehadap masalah hukum. Tahapan kedua penelitian hukum normative adalah penelitian yang ditujukan untuk mendapatkan hukum subjektif (hak dan kewajiban). ${ }^{2}$ Di dalam metode penelitian hukum normative, terdapat 3 macam bahan yang dipustaka yang dipergunakan oleh penulis yakni:

1. Bahan Hukum Primer. Bahan hukum ini merupakan bahan hokum yang mengikat atau yang membuat orang taat pada hukum seperti peraturan perundangundangan, dan putusan hakim. Bahan hukum primer yang penulis gunakan di dalam penulisan ini yakni: Undang-Undang Nomor 20 Tahun 2016 tentang Merek dan Indikasi Geografis

2. Bahan Hukum Sekunder. Bahan hukum ini diartikan sebagai bahan hukum yang tidak mengikat tetapi menjelaskan mengenai bahan hukum primer yang merupakan hasil olahan pendapat atau pemikiran para pakar atau ahli yang mempelajari suatu bidang tertentu secara khusus yang akan memberikan petunjuk ke mana penelitian akan mengarah. Yang

1 Soerjono Soekanto dan Sri Mamudi, Penelitian Hukum Normatif Suatu Tinjauan Singkat, Cetakan ke- 11, Jakarta, PT Raja Grafindo Persada, 2009, hlm 13-14

Hardijan Rusli, "Metode Penelitian Hukum Normatif: Bagaimana?”, Law Riview Fakultas Hukum Universitas Pelita Harapan, Volume V No. 3 tahun 2006, hlm 50 
dimaksud dengan bahan sekunder di sini oleh penulis adalah doktrindoktrin yang di dalam buku, jurnal hukum, dan internet.

3. Bahan Hukum Tersier. Bahan hukum ini adalah bahan hukum yang mendukung bahan hukum primer dan bahan hukum sekunder dengan memberikan pemahaman dan pengertian atas bahan hukum lainnya. Bahan hukum yang di pergunakan oleh penulis adalah Kamus Besar Bahasa Indonesia dan Kamus Hukum.

Di dalam penelitian hukum terdapat beberapa pendekatan. Dengan pendekatan tersebut, peneliti akan mendapatkan informasi dari berbagai aspek mengenai isu yang sedang di coba untuk di cari jawabannya. Adapun pendekatan yang digunakan di dalam penelitian hukum adalah Pendekatan Undang-Undang (statute approach). Pendekatan undangundang dilakukan dengan menelaah semua undnag-undang dan regulasi yang bersangkut paut dengan isu hukum yang sedang ditangani ${ }^{3}$.

\section{PEMBAHASAN}

Formulasi Merek dalam UndangUndang Nomor 20 Tahun 2016 tentang Merek dan Indikasi Geografis memberikan cakupan perlindungan yang lebih luas mengenai merek. Pada awalnya menurut

3 Pater Mahmud Marzuki, Penelitian Hukum, Jakarta, Kencana Prenada Media Group, 2009, hlm 93
Undang-Undang Nomor 15 Tahun 2001 tentang Merek dimana merek mencakup tanda yang berupa gambar, nama, kata, huruf-huruf, angka-angka, susunan warna, atau kombinasi dari unsur-unsur tersebut yang memiliki daya pembeda dan digunakan dalam kegiatan perdagangan barang atau jasa. Perluasan definisi merek menurut Undang-Undang Nomor 20 Tahun 2016 tentang Merek dan Indikasi Geografis membwa konsekuensi berupa perluasan ruang lingkup perlindungan merek. Perluasan perlindungan tersebut terdiri dari merek tiga dimensi, suara dan hologram. Hal tersebut patut diapresiasi sebagai upaya mengakomodir perkembangan terkini dalam dunia perdagangan, contohnya peningkatan teknologi digital dan multimedia yang kian pesat berimbas secara luas terhadap kegiatan perdagangan barang dan jasa. ${ }^{4}$

Daya pembeda pada suatu produk tidak hanya berupa tanda dua dimensi, tetapi muncul pula berupa tanda tiga dimensi, hologram, suara, aroma, tekstur bahkan rasa. Unsur-unsur tersebut juga memberikan daya pembeda yang cukup signifikan pada produk. Selanjutnya salah

4 R.F. Mayana, "Perlindungan Merek Non Tradisional Untuk Produk Ekonomi Kreatif Berdasarkan Undang-Undang Nomor 20 Tahun 2016 Tentang Merek, Indikasi Geografis dan Perspektif Perbandingan Hukum" Jurnal Bina Mulia Hukum Volume 2, Nomor 1, September 2017, hlm.28 
satu perkembangan di bidang merek adalah munculnya perindungan terhadap tipe merek baru yang disebut sebagai merek non-tradisional. Dalam Undang-Undang Nomor 20 Tahun 2016 tentang Merek dan Indikasi Geografis, lingkup merek yang dilindungi meliputi pula merek suara, merek tiga dimensi, merek hologram, yang merek-merek tersebut termasuk dalam kategori merek non-tradisional. Perkembangan teknologi memberikan pengaruh yang sangat besar juga untuk perkembangan hukum serta undangundang, karena setiap teknologi mengalami pembaharuan maka dari aspek hukum pun juga ikut diperbaharui.

Hologram merupakan salah satu dari sekian banyaknya jenis merek yang sedang berkembang dan masih sedikit orang yang menggunakan serta membuat suatu objek dengan menggunakan teknologi hologram. Hal ini juga yang menjadi alasan mengapa hologram tidak bisa dibuat oleh sembarang orang atau bahkan perlu dibuat secara khusus oleh orang-orang yang memang memiliki keahlian dalam bidang tersebut. Merekmerek non-tradisional yang sudah terdaftar di Indonesia diantaranya adalah merek 3 dimensi coklat ritter Sport (Ritter $\mathrm{GmbH}$ ) dan Radiator Grill BMW (Bayerische Motoren Werke Aktiengesellschaft). ${ }^{5}$

Gambar 1. Merek Ritter GmbH

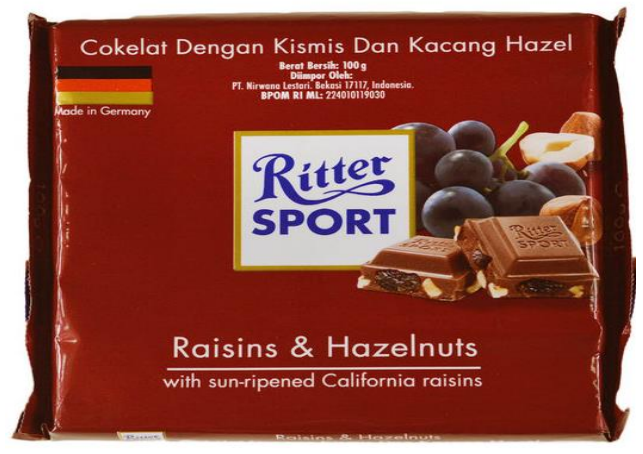

Gambar 2. Merek Radiator Grill BMW

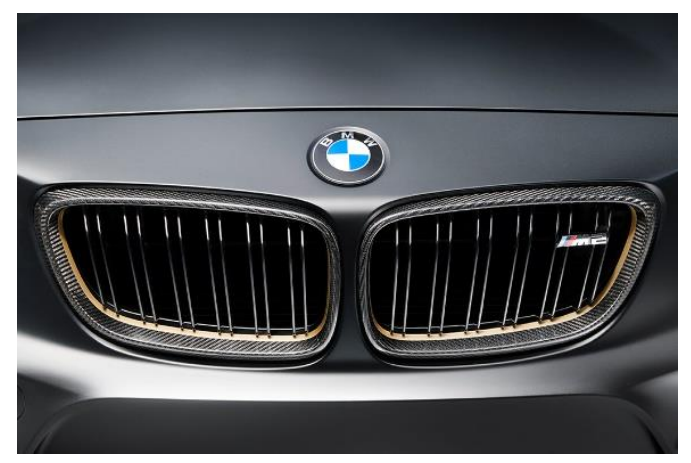

Tipe merek non-tradisioal itu diatur dalam Undang-Undang Nomor 20 Tahun 2016 tentang Merek dan Indikasi Geografis. Direktur Merek dan Indikasi Geografis Apabila melihat kembali pada UU Merek sebelumnya yang hanya mencakup tentang aturan pendaftaran merek konvensional. Maka para wetgever

5 Risa Amrikasari, "Dasar Hukum Perlindungan Merek Non-Tradisional”, Artikel dalam Hukumonline, dapat diakses pada https://www.hukumonline.com/klinik/detail/ulasan/ lt5bee57cd0c924/dasar-hukum-perlindunganmerek-non-tradisional diakses Selasa, 6 November 2019, Pukul 16.44 WITA 
menginisasi adanya penambahan cakupan yang tujuannya, agar kekayaan intelektual semakin meningkat.

Merek yang ada di dunia saat ini sudah memilik beragam model, jenis dan bentuk. Perlindungannya pun di masing masing jenis atau negara bisa berbeda. Namun, merek yang ada sekarang sebagian ada yang menimbulkan masalah karena dianggap mirip atau menyerupai suatu merek yang memang sudah terkenal. ${ }^{6}$ Lalu di Indonesia merek seperti apakah yang mendapatkan perlindungan sebagai salah satu merek yang terdaftar? Jadi, kriteria merek yang akan mendapat perlindungan hukum pastinya haruslah memiliki daya pembeda dan dipergunakan dalam barang atau jasa, dan dapat juga berupa ${ }^{7}$ :

a. Gambar, seperti lukisan burung garuda pada logo Garuda Indonesia atau gambar kelinci pada logo Dua Kelinci;

b. Kata, seperti Google, Toyota, atau Mandiri;

c. Nama, seperti Tommy Hilfiger atau Salvatore Ferragamo;

d. Frasa, seperti Sinar Jaya atau Air Mancur;

${ }^{6}$ Besar, "Cakupan Baru Merek Dagang: Belajar dari Jepang”, Rubric of Faculty Member, Business Law Binus University, dapat diakses https://business-

law.binus.ac.id/2016/09/30/cakupan-baru-merekdagang-belajar-dari-jepang/ diakses tanggal 5 November 2019 Pukul 11.50 WITA.

${ }^{7}$ Anonim,

"Merek", http://www.hki.co.id/merek.html diakses pada tanggal 5 November 2019 Pukul 12.05 WITA e. Kalimat, seperti Building for a Better Future atau Terus Terang Philip Terang Terus;

f. Huruf, seperti huruf " $F "$ pada logo Facebook atau huruf "K" pada logo Circle-K;

g. Huruf-huruf, seperti IBM atau DKNY;

h. Angka, seperti angka "7" pada logo Seven Eleven atau angka "3" pada logo provider GSM Three;

i. Angka-angka, seperti merek rokok 555 atau merek wewangian 4711;

j. Susunan warna, seperti pada logo Pepsi atau Pertamina;

k. Bentuk 3 (tiga) dimensi;

1. Suara;

m. Hologram;

n. Kombinasi dari unsur-unsur tersebut.

Seperti yang sudah disebutkan diatas, bahwa hologram termasuk dalam merek yang dilindungi di Indonesia, lalu bagaimanakah hologram bisa mendapatkan perlindungan hukum? Hologram dianggap memiliki perlindungan hukum apabila menampilkan warna yang berbeda dari sudut pandang yang sama namun Merek jenis ini dianggap sama dan tidak mendapatkan perlindungan hukum apabila memunculkan tampilan warna yang sama dari sudut pandang yang sama. ${ }^{8}$.

Jangka waktu perlindungan merek hologram, yaitu 10 tahun sejak tanggal pendaftaran, maka apabila terjadi pelanggaran yang dilakukan oleh pihak 
lain terhadap merek terdaftar tersebut (diantaranya menggunakan merek terdaftar tersebut pada produk-produk lain diluar produk yang diproduksi saudara sebagai pemilik merek terdaftar), dapat mengajukan gugatan terhadap pihak yang melakukan pelanggaran tersebut berdasarkan ketentuan UU Merek yang berlaku. $^{9}$

Permohonan pendaftaran merek diajukan dengan mengisi formulir rangkap 2 (dua) dalam bahasa Indonesia oleh Pemohon atau kuasanya kepada Direktorat Jenderal Kekayaan Intelektual ("Ditjen HKI”). Permohonan dapat diajukan secara elektronik atau non-elektronik. Selanjutnya permohonan paling sedikit memuat :

a. tanggal, bulan, dan tahun Permohonan

b. nama lengkap, kewarganegaraan, dan alamat Pemohon

c. nama lengkap dan alamat Kuasa jika Permohonan diajukan melalui Kuasa

d. nama negara dan tanggal permintaan Merek yang pertama kali dalam hal Permohonan diajukan dengan Hak Prioritas

e. label Merek

f. warna jika Merek yang dimohonkan pendaftarannya menggunakan unsur warna; dan

\footnotetext{
${ }^{9}$ Bung Pokrol, "Perlindungan Atas Hak Merek", artikel dimuat pada Hukumonline, https://www.hukumonline.com/klinik/detail/ulasan/ cl4430/perlindungan-atas-hak-merek/ diakses pada tanggal 15 Desember 2019 pukul 21.17 WITA.
}

g. kelas barang dan/atau kelas jasa serta uraian jenis barang dan/atau jenis jasa.

Dalam mengajukan Permohonan, pemohon juga harus melampirkan dokumen:

a. bukti pembayaran biaya Permohonan

b. label Merek sebanyak 3 (tiga) lembar, dengan ukuran paling kecil 2 × $2 \mathrm{~cm}$ (dua kali dua sentimeter) dan paling besar $9 \mathrm{x}$ $9 \mathrm{~cm}$ (sembilan kali sembilan sentimeter);

c. surat pernyataan kepemilikan Merek;

d. surat kuasa, jika Permohonan diajukan melalui Kuasa;

e. bukti prioritas, jika menggunakan Hak Prioritas dan terjemahannya dalam bahasa Indonesia.

Apabila yang akan didaftar berupa merek 3 (tiga) dimensi, maka label merek yang dilampirkan dalam bentuk karakteristik dari merek tersebut yang berupa visual dan deskripsi klaim pelindungan. Untuk pendaftaran merek suara, label merek yang dilampirkan berupa notasi dan rekaman suara. Apabila merek suara tersebut tidak dapat ditampilkan dalam bentuk notasi, maka label merek yang dilampirkan dalam bentuk sonogram. Untuk pendaftaran merek hologram, maka label merek yang dilampirkan berupa tampilan visual dari berbagai sisi. 
Dalam hal permohonan telah memenuhi persyaratan dokumen, maka permohonan tersebut akan diberikan tanggal penerimaan, dan kemudian diumumkan oleh Ditjen HKI dalam Berita Resmi Merek selama 2 (dua) bulan. Pada masa pengumuman tersebut, setiap pihak dapat mengajukan keberatan tertulis kepada Ditjen HKI sehubungan dengan permohonan pendaftaran merek tersebut.

Setiap permohonan akan dilakukan pemeriksaan terhadap kelengkapan dokumen persyaratan. Pemeriksaan dilakukan paling lama 15 (lima belas) hari terhitung sejak tanggal penerimaan. Dalam hal berdasarkan hasil pemeriksaan, permohonan dinyatakan lengkap dan telah melampaui jangka waktu pengumuman, permohonan dilakukan pemeriksaan substantif oleh pemeriksa. Pemeriksaan substantif dilakukan dalam jangka waktu paling lama 150 hari. Apabila tidak ada keberatan ataupun komentar dari pemeriksa maka hasil pemeriksaan harus diumumkan di Berita Resmi Merek selama dua bulan. Pada tahap ini, publik dapat memberikan keberatan terhadap merek yang diumumkan dengan memberikan pemberitahuan tertulis. Namun, apabila tidak ada keberatan maka dalam waktu 30 (tiga puluh) hari sebelum berakhirnya masa

pengumuman, Ditjen HKI dapat menerbitkan sertifikat merek. ${ }^{10}$

Gambar 3. Mekanisme Pendaftaran Merek

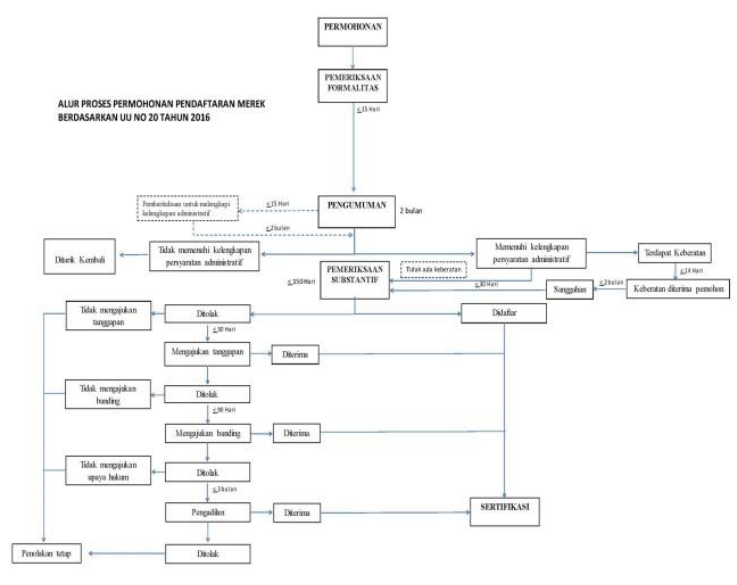

\section{PENUTUP}

Hologram termasuk kedalam hak merek Menurut Undang-Undang Nomor 20 Tahun 2016 Pasal 1 tentang Merek dan Indikasi geografis. Hologram termasuk dalam kategori merek non-tradisional. tipe merek non tradisional ini diatur dalam salah satu pasal UU merek dan indikasi geografis disahkan oleh dewan perwakilan rakyat. Tujuannya agar kekayaan intelektuan semakin menjamur di era ekonomi yang kreatif sekarang ini. Merek yang ada di dunia saat ini sudah memilik

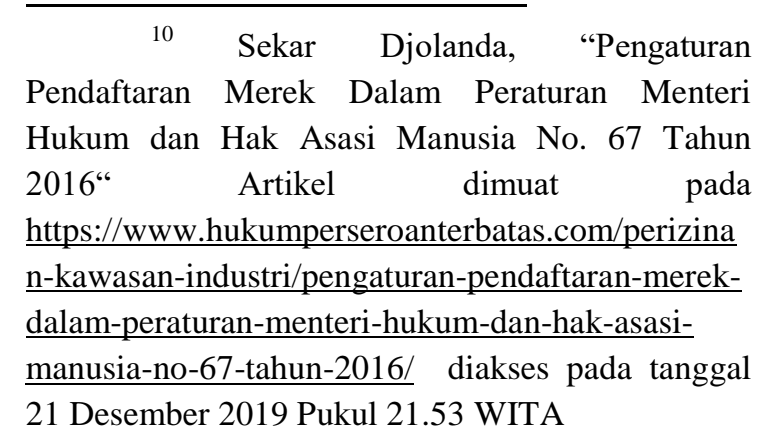


beragam model, jenis dan bentuk.

Perlindungannya pun di masing masing jenis atau negara bisa berbeda. Seperti yang sudah disebutkan bahwa hologram termasuk merek yang dilindungi di Indonesia dan pendaftarannya pun sekarang lebih mudah dalam Undangundang Nomor 20 tahun 2016, jangka waktu perlindungannya sama dengan tipe merek yang lain, yaitu 10 tahun.

\section{DAFTAR PUSTAKA}

\section{Buku}

Pater Mahmud Marzuki. 2009. Penelitian Hukum, Jakarta, Kencana Prenada Media Group.

Soerjono Soekanto dan Sri Mamudi. 2009. Penelitian Hukum Normatif Suatu Tinjauan Singkat, Cetakan ke- 11, Jakarta, PT Raja Grafindo Persada.

\section{Peraturan Perundang-Undangan}

Undang-Undang No. 20 Tahun 2016 Tentang Merek dan Indikasi Geografis

\section{Jurnal}

Hardijan Rusli, "Metode Penelitian Hukum Normatif: Bagaimana?" Law Review Fakultas Hukum Universitas Pelita Harapan, Volume V No. 3, 2006.

R.F. Mayana, "Perlindungan Merek Non Tradisional Untuk Produk Ekonomi Kreatif Berdasarkan Undang-Undang Nomor 20 Tahun 2016 Tentang Merek, Indikasi Geografis dan Perspektif Perbandingan Hukum" Jurnal Bina Mulia
Hukum Volume 2, Nomor 1, September 2017

\section{Website}

Risa Amrikasari, "Dasar Hukum Perlindungan Merek NonTradisional", Artikel dalam Hukumonline, dapat diakses pada

https://www.hukumonline.com /klinik/detail/ulasan/lt5bee57cd 0c924/dasar-hukumperlindungan-merek-nontradisional diakses Selasa, 6 November 2019, Pukul 16.44 WITA

Besar, "Cakupan Baru Merek Dagang: Belajar dari Jepang", Rubric of Faculty Member, Business Law Binus University, dapat diakses https://businesslaw.binus.ac.id/2016/09/30/cak upan-baru-merek-dagangbelajar-dari-jepang/ diakses tanggal 5 November 2019 Pukul 11.50 WITA.

Anonim, $\mathrm{ml}$ diakses pada tanggal 5 November 2019 Pukul 12.05 WITA

Bung Pokrol, "Perlindungan Atas Hak Merek", artikel dimuat pada Hukumonline, https://www.hukumonline.com /klinik/detail/ulasan/cl4430/per lindungan-atas-hak-merek/ diakses pada tanggal 15 Desember 2019 pukul 21.17 WITA. 
Sekar Djolanda, "Pengaturan Pendaftaran Merek Dalam Peraturan Menteri Hukum dan Hak Asasi Manusia No. 67 Tahun 2016“ Artikel dimuat pada https://www.hukumperseroante rbatas.com/perizinan-kawasanindustri/pengaturanpendaftaran-merek-dalamperaturan-menteri-hukum-danhak-asasi-manusia-no-67-

tahun-2016/ diakses pada tanggal 21 Desember 2019 Pukul 21.53 WITA 